\title{
Chemical Composition and Characteristics of Taverniera Cuneifolia (Roth) Ali Seed Oil
}

Mangalorkar $\mathbf{P}^{1 *}$, Joshi $\mathbf{H}^{2}$ and Nagar $\mathbf{P}^{2}$

${ }^{1}$ Department of Botany, Science Faculty, The Maharaja Sayajirao University of Baroda, Vadodara, Gujarat, India

${ }^{2}$ Department of Chemistry, Saurashtra University, Rajkot, Gujarat, India

\begin{abstract}
The seeds of Taverniera cuneifolia (Roth) Ali contains $6.24 \pm 0.41 \%$ oil. The fatty acid composition of Taverniera cuneifoia seeds was studied: a potential substitute of Licorice. Gas liquid chromatography of the methyl esters of the fatty acids shows the presence of $25.73 \%$ saturated fatty acids and $68.69 \%$ unsaturated fatty acids. The fatty acid composition is as follows: palmitic acid $20.72 \%$, stearic acid $5.01 \%$, oleic acid $16.99 \%$ and linoleic acid $51.70 \%$.
\end{abstract}

Keywords: Taverniera cuneifolia; Indian licorice; Fatty acids; Seeds

\section{Introduction}

The genus Taverniera belongs to the family of Fabaceae and includes twelve species. It is endemic to the Northeast African and Southwest Asian countries [1]. It is often referred to as Indian licorice owing to its sweet taste which is very similar to that of G. glabra [2]. Taverniera cuneifolia, locally known as Jethimadh is used by the tribal's of Barda Hills of Jamnagar in Western India as a substitute of Licorice or in other words the plant itself is considered to be G. glabra [3]. It is known to have various medicinal properties like expectorant, blood purification, antiulcer, anti-inflammatory, wound healing, and used in treating spleen tumors [4]. In addition, the seeds of T. cuneifolia are a potential source of edible pulse during extreme drought conditions used by the tribes of Barda Hills, Saurashtra, Gujarat, India [5]. Thus it is important to know its nutritional potential and oil compostion. There is no documentation on the oil content, chemical properties and fatty acid composition of Taverniera cuneifolia seed oil (TCSO). The purpose of the present work is to study the chemical properties and fatty acid composition of the TCSO.

\section{Experimental methods}

\section{Sampling}

The fresh fruits of $T c$ were collected from Munjka village, Rajkot, Gujarat, India during the favorable season between March and May. The specimens collected were identified with the help of the Flora of Gujarat State. Further the species was confirmed by comparison with the specimen lying in the herbaria of Botanical Survey of India, Jodhpur, Rajasthan, India (BSI/AZC I. 12012/ Tech./2011-12 (Pl.ID.)551. The $T c$ seeds were powdered without removing the fruit cover and were then extracted with petroleum ether $\left(60-80^{\circ} \mathrm{C}\right)$ in a Soxhlet apparatus. The extract was at that juncture filtered and distilled off in a rotary evaporator leaving behind dark olive coloured greenish oil. It was assessed for its various chemical properties by AOCS standard methods [6]. Replicates were taken for the analysis of chemical properties (Tables 1,2)

\section{GLC Analysis}

Samples were taken for the analysis of the fatty acid composition. The methyl esters of extracted oil were prepared in accordance with the Bureau of Indian Standards (BIS-548, part III). A NUCON-GLC chromatograph with a flame ionization detector (FID) was used for the analysis in which nitrogen gas was used as a carrier gas. The column used was $30 \mathrm{M}$ X $0.53 \mathrm{~mm}$ I.D. $5.0 \mu \mathrm{m}$ DB-1 Type MXT-1 capillary column. The injection port temperature was $250^{\circ} \mathrm{C}$ and the detector temperature was $280^{\circ} \mathrm{C}$. Sample injection was done at $60^{\circ} \mathrm{C}$ and the temperature programming was fixed at $2^{\circ} \mathrm{C}$ rise per minute to a maximum of $280^{\circ} \mathrm{C}$. The total run time was $40 \mathrm{~min}$. Identification of component was prepared by comparing its retention time with that of a Sigma-Aldrich standard fatty acids mixture.

\section{Results and Discussion}

The oil content in TC was found to be $6.24 \pm 0.41 \%$. The study shows that the oil is composed of four fatty acids with $25.73 \%$ saturated fatty acids and $68.69 \%$ unsaturated fatty acids. The saturated fatty acids are palmitic acid $(20.72 \%)$ and stearic acid $(5.01 \%)$ while unsaturated fatty acid includes oleic acid (16.99\%) and linoleic acid (51.70\%). Half

\begin{tabular}{|l|c|c|}
\hline Fatty acid & Isomers & $\%$ Composition \\
\hline Saturated fats & $(16: 0)$ & $20.72 \pm 5.95$ \\
\hline Palmitic & $(18: 0)$ & $5.01 \pm 0.96$ \\
\hline Stearic & $(18: 1 n 9 c)$ & $16.99 \pm 1.90$ \\
\hline Monounsaturated fats & \multicolumn{2}{|l|}{} \\
\hline Oleic & $(18: 2 n 6 c)$ & $51.70 \pm 3.69$ \\
\hline Polyunsaturated fats & & $25.73 \pm 6.91$ \\
\hline Linoleic & & $68.69 \pm 5.59$ \\
\hline Saturated & &
\end{tabular}

Table 1: Extraction and Analysis of Oil.

\begin{tabular}{|c|c|}
\hline Determination & Present study (\%) \\
\hline Acid value & $32.66 \pm 3.16$ \\
\hline Saponification value & $162.55 \pm 2.33$ \\
\hline lodine value & $88.31 \pm 10.96$ \\
\hline
\end{tabular}

Table 2: Chemical properties of TCSO

*Corresponding author: Poonam Mangalorkar, Department of Botany, Science Faculty, The Maharaja Sayajirao University of Baroda, Vadodara, Gujarat, India, Tel: +919974565885; E-mail: drmangalorkar@gmail.com

Received August 29, 2015; Accepted September 15, 2015; Published September 19,2015

Citation: Mangalorkar P, Joshi H, Nagar P (2015) Chemical Composition and Characteristics of Taverniera Cuneifolia (Roth) Ali Seed Oil. J Pharmacogn Nat Prod 6: 101. doi:10.4172/2472-0992.1000101

Copyright: ( 2015 Mangalorkar P, et al. This is an open-access article distributed under the terms of the Creative Commons Attribution License, which permits unrestricted use, distribution, and reproduction in any medium, provided the original author and source are credited. 
Citation: Mangalorkar P, Joshi H, Nagar P (2015) Chemical Composition and Characteristics of Taverniera Cuneifolia (Roth) Ali Seed Oil. J Pharmacogn Nat Prod 6: 101. doi:10.4172/2472-0992.1000101

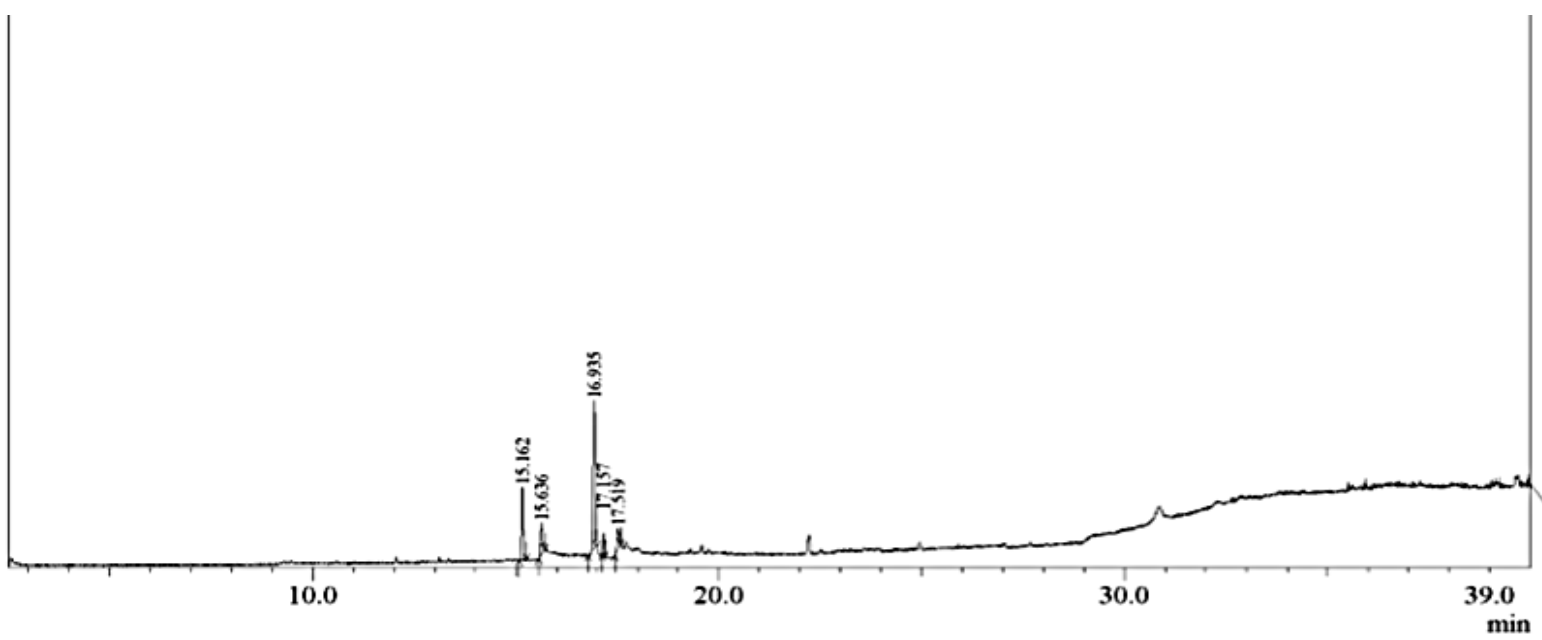

Peak Repon TIC

\begin{tabular}{|r|r|r|r|r|r|}
\hline Peak & R.Time & Area & Area\% & Height & Name \\
\hline 1 & 15.162 & 424820 & 15.51 & 201275 & \\
\hline 2 & 15.636 & 284187 & 10.38 & 87180 & \\
\hline 3 & 16.935 & 1611089 & 58.84 & 413599 & \\
\hline 4 & 17.157 & 139663 & 5.10 & 64525 & \\
\hline 5 & 17.519 & 278480 & 10.17 & 61187 & \\
\hline & & 2738239 & 100.00 & 827766 & \\
\hline
\end{tabular}

Hit \#:1 Entry:822 Library:PMW_TOX2.LIB

SI:88 Formula:C16H32O2 CAS:57-10-3 MolWeight:256 RetIndex:0

CompName:Palmitic acid P1210

100

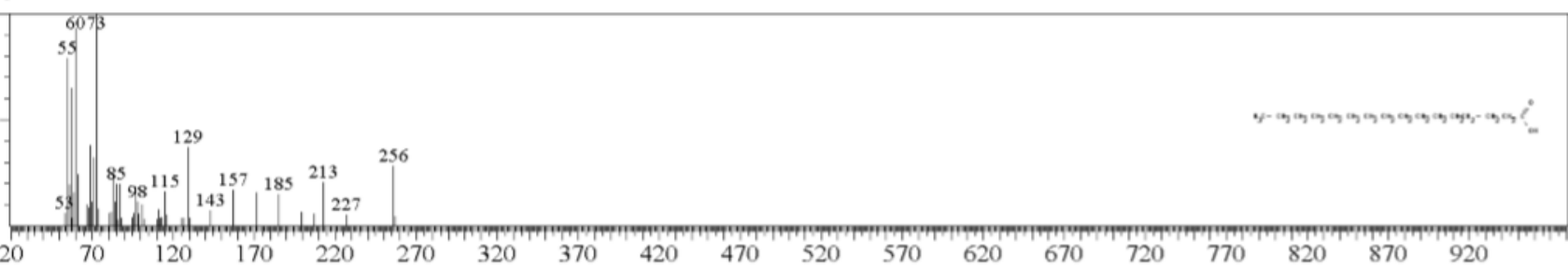

Hit \#:3 Entry:193351 Library:WILEY7.LIB

SI:73 Formula:C18 H34 O2 CAS:112-80-1 MolWeight:282 RetIndex:0

CompName:9-Octadecenoic acid (Z)- (CAS) Oleic acid \$\$ Red oil \$\$ Oelsauere \$\$ Oleine 7503 \$\$ Pamolyn 100 \$\$ Emersol 211 \$S Vopcolene 27 \$\$ cis-Oleic

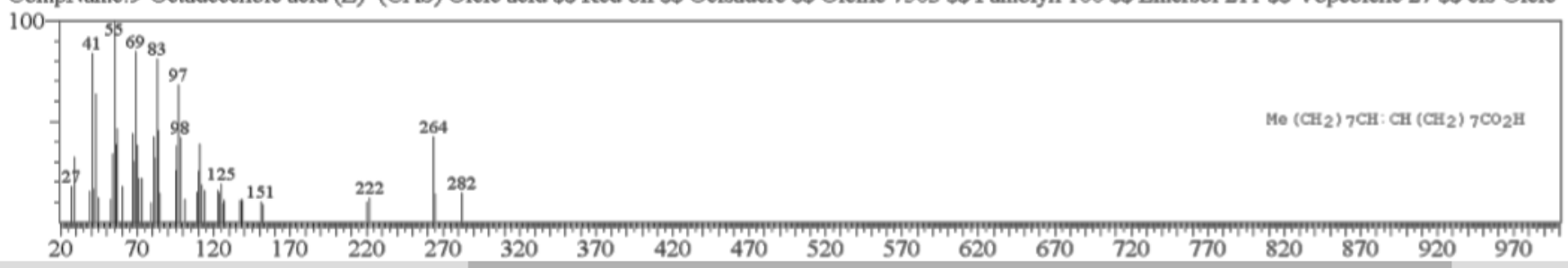

Hit\#:2 Entry:209854 Library:WILEY7.LIB

SI:81 Formula:C19 H38 O2 CAS:112-61-8 MolWeight:298 RetIndex:0

CompName:Octadecanoic acid, methyl ester (CAS) Methyl stearate \$\$ Methyl octadecanoate \$\$ Methyl n-octadecanoate \$S Stearic acid methyl ester \$\$ Kemest

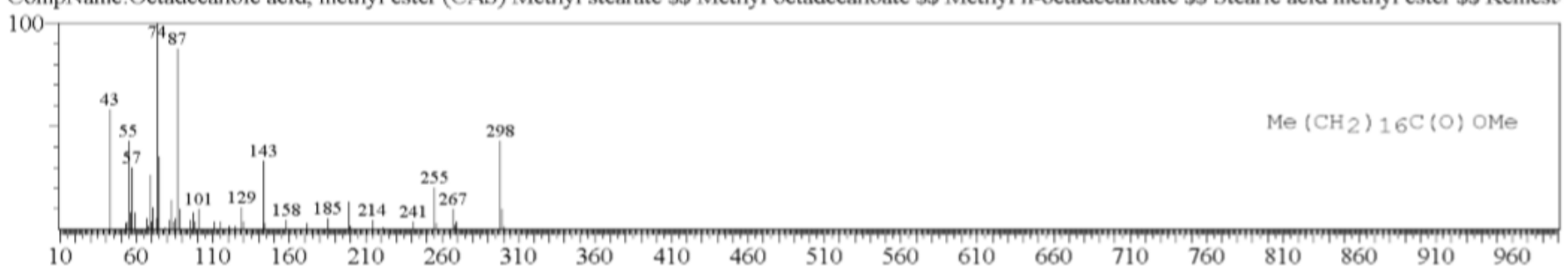

Figure 1: GLC analysis of the fatty acid composition in Taverniera cuneifolia seed oil. 
Citation: Mangalorkar P, Joshi H, Nagar P (2015) Chemical Composition and Characteristics of Taverniera Cuneifolia (Roth) Ali Seed Oil. J Pharmacogn Nat Prod 6: 101. doi:10.4172/2472-0992.1000101

Page 3 of 3

of the FA composition is of linoleic acid (6-omega FA). The total seed oil fatty acid composition of Glycyrrhiza uralensis Fisch. is $61.84 \%$ consisting of linoleic acid 24.3\%, a-linolenic acid $25.51 \%$, stearic acid $3.02 \%$, palmitic acid $7.98 \%$ [7]. The oil composition of $T c$ is having quite similar Fatty acid composition as that of Sesamum indicum [8], Madhuca indica [9], Carthamus tinctorius [10] and Prunus amygdalus [11]. The oil composition of T. cuneifolia varies with that of fabaceae members like, Crotolaria juncea [12], Medicago spps [13], Arachis hypogea [14], Glycine max [15] (Figure 1).

\section{Conclusion}

The study provided the evidence that the TCSO has the presence of Poly Unsaturated Fatty Acid (PUFA), Mono Unsaturated Fatty Acids (MUFA) and Saturated Fatty Acids (SFA).

\section{Acknowledgement}

The authors wish to thank the University Grants Commission, New Delhi for providing research grant.

\section{References}

1. Naik VN (1998) Flora of Marathwada (Ranunculaceae to Convolvulaceae) Amrut Prakashan, Aurangabad.

2. Zore GB (2005) Pharmacological studies of Taverniera cuneifolia (Roth) Arn, a substitute for commercial liquorice. Ph.D. Thesis in Biotechnology, Swami Ramanand Teerth Marathwada university, Nanded.

3. Nagar PS (2005) Floristic biodiversity of Barda Hills and its surroundings Scientific publishers, Jodhpur.

4. Thaker J (1910) Kathiyawadna Barda dungarni jadibuti teni pariksha ane upyog, The Gujarati Press Publishers, Mumbai.
5. Shah GL (1978) The Flora of Gujarat State. (1 ${ }^{\text {st }}$ edn) Vallabh Vidyanagar: Sardar Patel University, India.

6. Link WE (1973) Official and tentative methods of the American Oil Chemist's society. ( $3^{\text {rd }}$ edn) AOCS: Champaign, Chicago.

7. Fu YJ, Wang W, Zu YG, Suschke U, Reichling J, et al. (2007) Supercritical Fluid Extraction of Seed Oil from Chinese Licorice (Glycyrrhiza uralensis Fisch.) Chemical composition and Antibacterial Activity. S Afr J Chem 60: 67-70.

8. Nzikou JM, Matos L, Bouanga-Kalou G, Ndangui CB, Pambou-Tobi NPG, et al. (2009) Chemical Composition on the Seeds and Oil of Sesame (Sesamum indicum L.) grown in Congo-Brazzaville. Adv J Food Sci Technol 1: 6-11.

9. Singh B, Bux F, Sharma YC (2011) Comparison of homogeneous and heterogeneous catalysis for synthesis of biodiesel from Madhuca indica oil. $\mathrm{Cl}$ \& CEQ 17: 117-124.

10. Shahidi F (2005) Bailey's Industrial Oil and Fat Products $\left(6^{\text {th }}\right.$ edn) John Wiley \& Sons, Canada Pp: 491-536.

11. Abdallah A, Ahumada MH, Gradzeil TM (1998) Oil content and fatty acid composition in almond kernels from different genotypes and California production regions. J Amer Soc Hort Sci 123: 1029-1033.

12. Chouhan HS, Sahu AN, Singh SK (2010) Fatty acid composition, antioxidant anti-inflammatory and antibacterial activities of seed oil from Crotalaria juncea L. J Med Plant Res 5: 984-991.

13. Bakoglu A, Bagci E, Kocak A, Yuce E (2010) Fatty Acid Composition of Some Medicago L. (Fabaceae) species From Turkey. Asian J Chemol 22: 651-656.

14. Dwivedi SL, Nigam SN, Nageswara RC, Singh U, Rao KVS (1996) Effect of drought on oil and fatty acids and protein contents of groundnut (Arachis hypogea $L$.) seeds. Field crops research 48: 125-133.

15. Shahidi F (2005) Bailey's Industrial Oil and Fat Products. ( $6^{\text {th }}$ edn) John Wiley \& Sons, Canada Pp: 577-653. 